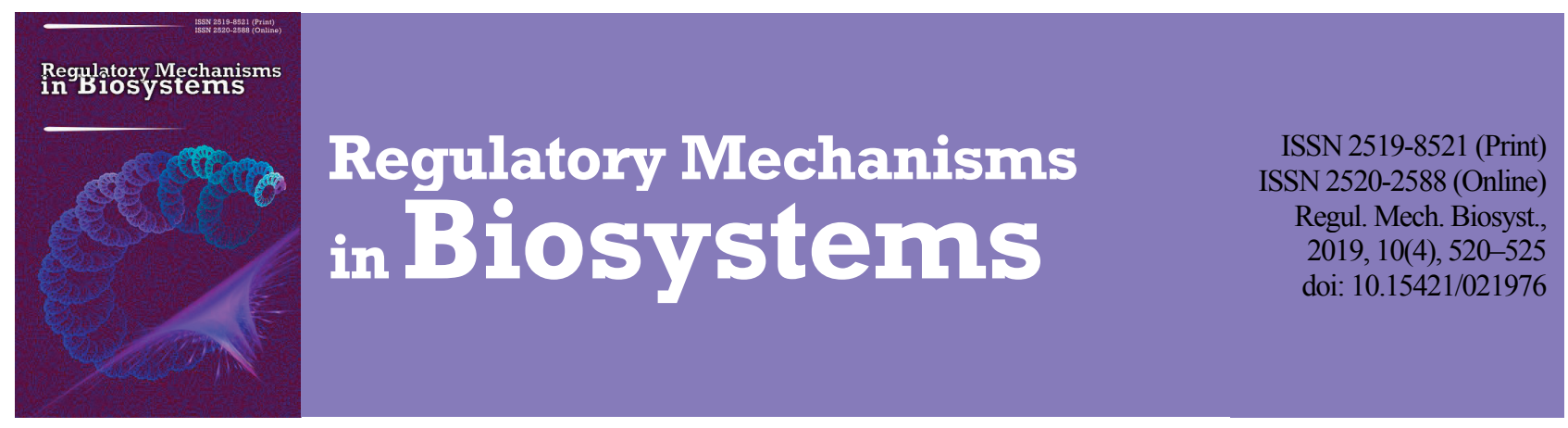

\title{
Fatty acids of lipids of blood serum and liver of rats with tetracyclin-induced hepatosis and at correction
}

\author{
V. Gryshchenko, S. Sysoliatin, S. Midyk \\ National University of Life and Environmental Sciences of Ukraine, Kyiv, Ukraine
}

Article info

Gryshchenko, V., Sysoliatin, S., \& Midyk, S. (2019). Fatty acids of lipids of blood serum and liver of rats with tetracyclin-induced
hepatosis and at correction. Regulatory Mechanisms in Biosystems, 10(4), 520-525. doi:10.15421/021976

Received 06.10.2019

Received in revised form 02.11 .2019

Accepted 03.11.2019

Irrational pharmacotherapy with tetracyclines can cause mitochondrial cytopathies of liver cells and the development of toxic dystrophy. The issue of violation of the qualitative and quantitative composition of fatty acids and their functional role in the development of liver dystrophy has not been studied enough. Therefore, the aim of the work was to determine the features of changes in

National University of Life and Environmental Sciences of Ukraine, Heroyiv Oborony st., 15 , Kyiv, 03041, Ukraine. Tel.: + 38-066-910-43-43. E-mail:

viktoriya004@ukr.net the fatty acid composition of blood serum and liver lipids in rats with tetracycline-induced hepatosis and the corrective efficacy of the phospholipid-acceptable dietary supplement "FLP-MD". It was experimentally established that, in the composition of blood serum lipids and liver tissue, key changes in modeling tetracycline-induced hepatosis in rats $(250 \mathrm{mg} / \mathrm{kg}$ for 7 days $)$ are primarily tested for polyene fatty acids (PUFAs). In blood serum this is manifested by a decrease in the level of docosadiienoic (22:2 $\omega 6$ ) and docosahexaenoic acid (22:6 63 ), as well as the total PUFA content due to representatives of the $\omega 3$ family, respectively, by 1.3 times. At the same time, a decrease in the content of eicosapentenoic (20:5 the saturated/unsaturated fatty acid (SFA/UFA) and $\omega 3 / \omega 6$ PUFA ratios, respectively, are noted in the lipid fraction of the liver, respectively by 1.3 times. In contrast to these animals, the use of reparative action of a phospholipid-acceptable dietary supplement "FLP-MD" (13.5 mg/kg) in sick rats provides a significant increase in the level of these fatty acids both in blood serum and in the liver and the restoration of their profile for other representatives. Thus, the components of the "FLP-MD" dietary supplement show a corrective effect on the fatty acid composition of the lipid component of blood serum and liver tissue of animals with tetracyclineinduced hepatosis. Indicators have been experimentally established for the diagnosis of toxic liver damage and preclinical trials of the hepatoprotective efficacy of new drugs, which is a promising area of research in veterinary hepatopathology.

Keywords: fatty degeneration; fatty acid composition; BAA "FLP-MD", corrective effect.

\section{Introduction}

Among the toxic compounds causing structural and functional changes in the liver in the form of fatty hepatosis, antibiotics (primarily the tetracycline series), which are often used in the treatment of various diseases, dominate (Madian, 2015). Despite the successes achieved in providing pharmacological correction of structural, functional and metabolic changes in the mammalian organism during liver pathology, the issues of violation of the composition of fatty acids and their functional role in the development of fatty degeneration are insufficiently studied (Bothra et al., 2018; Calitz et al., 2018; Kagebeck et al., 2018).

In the diet, four classes of fatty acids enter the body of mammals: saturated (SFA), monoenoic (MUFA), PUFA of the $\omega-6$ and $\omega-3$ family. Along with this, the fatty acid composition of the blood plasma and body tissues of mammals is significantly affected by age, gender, endocrine status, and genetic factors (Jump \& Clarke, 1999; Gula \& Margitich, 2009). At the same time, the total content of acyl-CoA in the cell varies significantly depending on the type of cell and some other factors. So, the amount of acyl-CoA in the liver tissue ranges $110-152 \mu \mathrm{M}$. Fatty acid metabolites play a key role in the expression of transcription factors. Fatty acids can structurally change under the influence of elongases and desaturases, be involved in the synthesis of complex lipids, in particular phospholipids and triacylglycerols, and also undergo oxidation (Wie et al., 2018).

The metabolic pathway through which fatty acid is converted depends on its structure and morphological type of tissue (Gula \& Margitich, 2009). At the same time, a number of genes whose activity is regulated by fatty acids are also controlled by products of other metabolic pathways.
This manifestation of the integration of general metabolism, which is regulated by dietary, endocrine, paracrine and autocrine factors, plays a vital role in maintaining cellular function at the proper level (Jamp \& Clarke, 1999). It has already been confirmed that a decrease in the functional activity of acyl-CoA oxidase, an important enzyme that catalyzes $\beta$-oxidation in peroxisomes, leads to the accumulation of very long chain fatty acids ( $C \geq 24)$ and liver steatosis (Fan et al., 1998). At the same time, the onset of pathological conditions is associated by most scientists with damage to biological membranes due to oxidative stress (Peter \& Prince, 2018). As a result of peroxidative destruction of polyene fatty acids, the liquidity of the membranes decreases, which leads to disruption of the activity of membrane-bound enzymes and the vital functions of cells. Such processes are also characteristic of tetracycline liver damage, which provoke changes in the functional state of hepatocyte membranes. Moreover, an increase in the activity of aminotransferases (aspartate aminotransferase and alanine aminotransferase), markers of the cytolytic process, is noted in the liver tissue (Nedoshytko, 2013).

It is known that phospholipid molecules are powerful factors in cellular repair, and can also serve as precursors of secondary messengers (Udut et al., 2013; Quinn, 2014; Yang et al., 2018). Many facts have now been accumulated about the participation of phospholipids in the activation of signal transduction processes in various pathological conditions, which has become the basis for the development of new drugs (Bothra et al., 2018; Colombo et al., 2018).

Experimental reproduction of toxic liver dystrophy is possible by introducing toxic doses of tetracycline hydrochloride into the body of laboratory animals (Madian, 2015). This allows preclinical trials of the 
therapeutic efficacy of newly hepatoprotective drugs (Yu et al., 2009). In tetracycline-induced hepatosis, there is a violation of the structural, including phospholipid, organization of cell membranes, intensive collagen formation with subsequent formation of fibrosis (Fabbrini \& Magkos, 2015). Recently, essential phospholipids have been used in therapeutic regimens for the development of fatty hepatosis (Grattagliano et al., 2013; Gryshchenko et al., 2018). This prompted a test of the reparative effectiveness of milk phospholipids, which are identical in fatty acid composition to the lipid component of biological membranes of mammalian tissues and organs. Therefore, the aim of our work was to determine the features of changes in the fatty acid composition of blood serum and liver lipids in rats with tetracycline-induced hepatosis and correcting the effectiveness of the phospholipid-containing dietary supplement "FLP-MD".

\section{Materials and methods}

All manipulations with rats were carried out in accordance with the requirements of the European Convention for the Protection of Vertebrate Animals Used for Experimental and Scientific Purposes (Strasbourg, 1986), the Law of Ukraine "On the Protection of Animals from Cruelty" No 3447 of 02.21 .2006 , which was confirmed by the conclusion of the Bioethics Commission of the National University of Life and Environmental Sciences of Ukraine, Kyiv, Ukraine.

Clinical studies were performed under the conditions of the Department of Animal Biochemistry and Physiology named after Academician M. F. Gulyi, determination of biochemical parameters - the Ukrainian Laboratory of Quality and Safety of Agricultural Products of the National University of Life and Environmental Sciences of Ukraine, Kyiv, Ukraine during 2018.

For the experiment, 60 white laboratory male Wistar rats with a body weight of 200-220 g were selected, the selection being according to the analogue principle (Vlizlo et al., 2012). Animals were separately housed in cages. Two weeks before the start of the experiment, the rats were quarantined with a daily clinical examination for two weeks. The animals received a balanced diet and had free access to food and drinking water.

At the beginning of the experiment, three groups of rats were formed (control and two experimental), 20 animals each. To reproduce the subacute form of fatty hepatosis according to our modified method, the rats of the first and second research groups (Gryshchenko et al., 2019) were for 7 days intragastrically administered a suspension of tetracycline hydrochloride in a $4 \%$ starch gel solution once a day at a dose of $250 \mathrm{mg} / \mathrm{kg}\left(0.25 \mathrm{LD}_{25}\right)$ using a probe. The animals in the control group were given a similar volume of double-distilled water.

During the experiment, the animals of the first experimental group were left without treatment (self-rehabilitation), and the animals of the second experimental group were intragastrically injected with a $1 \%$ solution of phospholipid-containing biologically active additives (BAA) "FLP-MD" in a liposome form at a dose of $13.5 \mathrm{mg} / \mathrm{kg}$ per one hour before the introduction of tetracycline hydrochloride and in the next two days after completion of the seed. Bioadditive "FLP-MD" is the author's development (Melnychuk et al., 2009), which includes a complex of milk phospholipids (nipples) that have a fatty acid spectrum natural for mammalian cell membranes, a mixture of unsaturated fatty acids (oleic, linoleic, linolenic), obtained with linseed oil, and antioxidants (vitamins $\mathrm{A}$ and $\mathrm{E}$ ).

The duration of the experiment was 9 days. The selection of biological material (blood and liver) in rats was performed on the 10th day of the experiment under ether anesthesia.

Methods of sample preparation and analysis of the fatty acid composition of the total lipid fraction of blood serum and liver. Blood for the study of the fatty acid composition of lipids was taken from the abdominal aorta of rats, which was subsequently centrifuged at $1500 \mathrm{rpm}$ for 15-20 minutes to obtain serum. In the experiments, rat liver samples were also used. Homogenization of liver samples was carried out in the cold in Potter-Elveem glass homogenizers in physiological saline (1:10). Lipids were extracted from blood serum and liver homogenates according to the method (Folch et al., 1957) of a chloroform-methanol mixture $(2: 1, \mathrm{v} / \mathrm{v})$. The extraction time was 12 hours. Non-lipid impurities were removed from the extract after adding $1 \%$ potassium chloride solution. Lipid extracts were stored in a freezer at a temperature of $-24^{\circ} \mathrm{C}$.

The lipid extract was transferred into glass vials with a sealed cap, $3 \mathrm{~N}$ was added, a solution of hydrochloric acid in methanol. Vials were placed in a boiling water bath "GFL-1002" (Germany) and hydrolysis was performed for $60 \mathrm{~min}$. Then the reaction mixture was cooled to room temperature. Fatty acid methyl esters (FAMEs) were extracted from the reaction mixture with hexane (Christive, 1982). Fatty acids were detected by gas-liquid chromatography on a Trace GC Ultra gas chromatograph (Thermo Scientific, USA) with a flame-ionization detector and an injector with temperature programming on a SPTM-2560 high-polar capillary column (Supelco, USA), length $100 \mathrm{~m}$, with an inner diameter of $0.25 \mathrm{~mm}$ and a thickness of the stationary phase of $0.20 \mu \mathrm{m}$. Separation parameters: detector temperature $-260^{\circ} \mathrm{C}$, injector temperature $-250{ }^{\circ} \mathrm{C}$, column thermostat temperature $-140-240{ }^{\circ} \mathrm{C}$, carrier gas (helium) flow rate $-25 \mathrm{~cm}^{3} / \mathrm{min}$, hydrogen flow rate $30 \mathrm{~cm}^{3} / \mathrm{min}$, air flow rate $-250 \mathrm{~cm}^{3} / \mathrm{min}$, pressure $-2.5 \mathrm{~atm}$. To identify the chromatographic peaks of fatty acids and to calculate chromatograms, we used a standard mixture of methyl esters of fatty acids 37 Compone FAME Mix (Supelco, USA) (DSTU ISO 5508-2001). Chromatograms were recorded and processed using a personal computer equipped with Xcalibur software (Thermo Scientific, USA). For the quantitative interpretation of individual fatty acids, the peak area normalization method was used and their number was presented as a percentage of the total content (Vlizlo et al., 2012).

The following fatty acids were obtained and quantified by gasliquid chromatography as a part of total serum lipids: caprylic (8:0), capric (10:0), lauric (12:0), myristic (14:0), pentadecanoic (15:0), palmitic (16:0), palmitoleic (16:1 $\omega 9)$, margarine (17:0), stearic (18:0), oleic

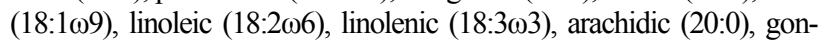

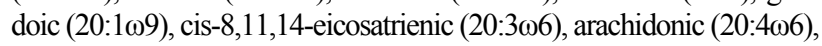

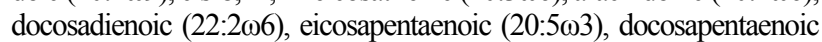

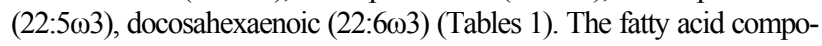
sition of the total lipids of rat liver includes the following acids: myristic

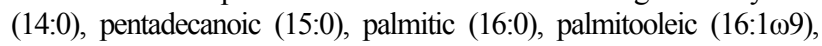

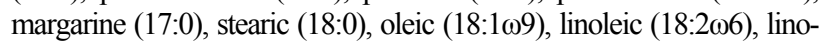

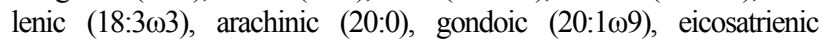

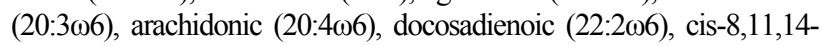
eicosapentaenoic (20:5 $\omega 3)$, docosapentaenoic $(22: 5 \omega 3)$, docosahexaenoic (C22:603) (Tables 2).

Analysis of the data was performed using Statistica 6.0 (StatSoft Inc., USA) program. The data are presented in tables as $\mathrm{x} \pm \mathrm{SD}$ (mean \pm standard deviation). Differences between the values in the control and experimental groups were determined using the Tukey test, where the differences were considered reliable at $\mathrm{P}<0.05$ (taking into account the Bonferroni correction).

\section{Results}

In rat blood serum, short, medium and long chain fatty acids were detected. Among SFA, palmitic and stearic dominate. Serum unsaturated fatty acids (UFAs) are heterogeneous: MUFAs are most commonly represented by oleic acid, linoleic, arachidonic and docosahexaenoic acids predominate among PUFAs (Tables 1). Qualitative and quantitative changes in the fatty acid composition of lipids in the pathogenesis of toxic liver damage with tetracycline are characterized by a number of features (Table 1). As a result of the study, it was found that the characteristic features of the fatty acid composition of the serum lipid fraction of rats with tetracycline-induced hepatosis were: a significant increase in the content of individual SFA representatives, in particular, caprylic acid (8:0) by 1.3 times, lauric acid (12:0) 1.1 times, margaric acid (17:0) 2.3 times and a significant increase in the level of the acid of the MUFA class - oleic $(18: 1 \omega 9) 1.4$ times compared with the intact control.

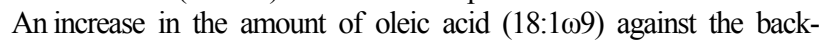
ground of a normal level of palmitic (16:0) and stearic (18:0) acids may indicate an increase in $\Delta 9$-desaturase activity in the tissues of sick rats with tetracycline-induced liver dystrophy. At the same time, the level of the main PUFAs of total lipids decreased in the blood serum: linoleic acid $(18: 2 \omega 6)$ by1.4 times, linolenic $(18: 3 \omega 3) 3.5$ times, cis- $8,11,14-$ 


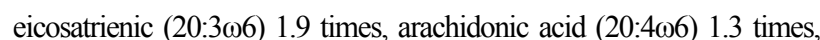

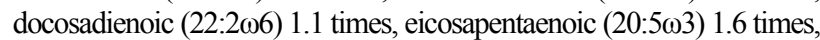
docosahexaenoic acid (22:6 103$) 1.2$ times, which affects the relative content of the sum of different families of these acids. In the sick animals, the total amount of SFA in the blood serum increased significantly 1.1 times, the ratio of the relative SFA/UFA content was 1.2 times and the MUFA level was 1.4 times compared to the control. The opposite tendency of changes in the total content of UFA, PUFA, $\omega 3$ PUFA and $\omega 6$ PUFA was revealed, 1.1 times, 1.3, 1.3 and 1.4 times, respectively. In turn, a decrease in the number of PUFAs, primarily docosahexaenoic acid (22:2 $\omega 6)$, was observed in violation of the $\beta$-oxidation of fatty acids in mitochondria.

Table 1

The fatty acid composition of total serum lipids of experimental rats ( $\%$ of the total fatty acid content, $\mathrm{x} \pm \mathrm{SD}, \mathrm{n}=20$ )

\begin{tabular}{|c|c|c|c|}
\hline Fatty acid & $\begin{array}{l}\text { Clinically } \\
\text { healthy } \\
\text { animals } \\
\text { (control) }\end{array}$ & $\begin{array}{l}\text { Rats with } \\
\text { tetracycline- } \\
\text { induced hepa- } \\
\text { tosis, self- } \\
\text { rehabilitation }\end{array}$ & $\begin{array}{l}\text { Rats with tetracycline- } \\
\text { induced hepatosis } \\
\text { supplemented with } \\
\text { dietary supplements } \\
\text { "FLP-MD" }\end{array}$ \\
\hline Caprylic, 8:0 & $0.09 \pm 0.01^{\mathrm{a}}$ & $0.12 \pm 0.01^{b}$ & $0.15 \pm 0.01^{\mathrm{c}}$ \\
\hline Capric, $10: 0$ & $0.20 \pm 0.01^{\mathrm{a}}$ & $0.22 \pm 0.01^{\mathrm{a}}$ & $0.25 \pm 0.01^{\mathrm{b}}$ \\
\hline Lauric, 12:0 & $0.27 \pm 0.01^{\mathrm{a}}$ & $0.30 \pm 0.01^{\mathrm{b}}$ & $0.30 \pm 0.01^{\mathrm{b}}$ \\
\hline Myristine, 14:0 & $0.40 \pm 0.02^{\mathrm{a}}$ & $0.41 \pm 0.01^{\mathrm{a}}$ & $0.40 \pm 0.01^{\mathrm{a}}$ \\
\hline Pentadecane, 15:0 & $0.29 \pm 0.01^{\mathrm{a}}$ & $0.30 \pm 0.02^{\mathrm{a}}$ & $0.31 \pm 0.01^{\mathrm{a}}$ \\
\hline Palmitic, 16:0 & $18.57 \pm 0.24^{\mathrm{a}}$ & $21.28 \pm 0.18^{\mathrm{a}}$ & $20.60 \pm 0.24^{\mathrm{a}}$ \\
\hline Palmitoleic, $16: 1 \omega 9$ & $0.90 \pm 0.04^{\mathrm{a}}$ & $0.90 \pm 0.01^{\mathrm{a}}$ & $0.91 \pm 0.01^{\mathrm{a}}$ \\
\hline Margarine, 17:0 & $0.04 \pm 0.01^{\mathrm{a}}$ & $0.09 \pm 0.01^{\mathrm{b}}$ & $0.09 \pm 0.01^{\mathrm{b}}$ \\
\hline Stearin, 18:0 & $18.14 \pm 0.08^{\mathrm{a}}$ & $20.16 \pm 0.11^{\mathrm{a}}$ & $18.19 \pm 0.11^{\mathrm{a}}$ \\
\hline Oleic, $18: 1 \omega 9$ & $15.74 \pm 0.53^{\mathrm{a}}$ & $22.15 \pm 0.07^{b}$ & $20.16 \pm 0.07^{\mathrm{c}}$ \\
\hline 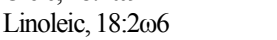 & $22.80 \pm 0.48^{\mathrm{a}}$ & $16.84 \pm 0.33^{b}$ & $20.82 \pm 0.79^{\mathrm{a}}$ \\
\hline Peanut, 20:0 & $0.24 \pm 0.01^{\mathrm{a}}$ & $0.26 \pm 0.01^{\mathrm{a}}$ & $0.24 \pm 0.01^{\mathrm{a}}$ \\
\hline Linolenic, $18: 3 \omega 3$ & $1.47 \pm 0.0^{\mathrm{a}}$ & $0.42 \pm 0.02^{b}$ & $0.57 \pm 0.01^{\mathrm{c}}$ \\
\hline Gondoic, 20:1 $\omega 9$ & $0.15 \pm 0.01^{\mathrm{a}}$ & $0.13 \pm 0.01^{\mathrm{a}}$ & $0.12 \pm 0.01^{\mathrm{a}}$ \\
\hline $\begin{array}{l}\text { cis-8,11,14-Eicosatriene, } \\
20: 3 \omega 6\end{array}$ & $2.14 \pm 0.05^{\mathrm{a}}$ & $1.13 \pm 0.01^{\mathrm{b}}$ & $1.46 \pm 0.25^{\mathrm{b}}$ \\
\hline 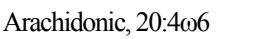 & $8.79 \pm 0.09^{\mathrm{a}}$ & $6.80 \pm 0.09^{b}$ & $4.80 \pm 0.08^{c}$ \\
\hline Docosadienoic, $22: 2 \omega 6$ & $1.13 \pm 0.02^{\mathrm{a}}$ & $1.03 \pm 0.03^{\mathrm{b}}$ & $1.81 \pm 0.03^{\mathrm{c}}$ \\
\hline Eicosapentaenoic, 20:5 & $1.81 \pm 0.06^{\mathrm{a}}$ & $1.16 \pm 0.01^{\mathrm{b}}$ & $1.06 \pm 0.02^{\mathrm{c}}$ \\
\hline Docosapentaenoic, $22: 5 \omega 3$ & $3.10 \pm 0.08^{\mathrm{a}}$ & $3.15 \pm 0.06^{\mathrm{a}}$ & $3.65 \pm 0.08^{\mathrm{b}}$ \\
\hline Docosahexaenoic, $22: 6 \omega 3$ & $3.71 \pm 0.05^{\mathrm{a}}$ & $3.14 \pm 0.04^{b}$ & $4.11 \pm 0.07^{\mathrm{c}}$ \\
\hline$\Sigma$ SFA & $38.24 \pm 0.73^{\mathrm{a}}$ & $43.15 \pm 0.89^{\mathrm{a}}$ & $40.53 \pm 0.92^{\mathrm{ab}}$ \\
\hline$\Sigma$ UFA & $61.73 \pm 1.02^{\mathrm{a}}$ & $56.85 \pm 0.74^{\mathrm{b}}$ & $59.47 \pm 0.86^{\mathrm{a}}$ \\
\hline SFA/UFA & $0.62 \pm 0.04^{\mathrm{a}}$ & $0.76 \pm 0.03^{b}$ & $0.68 \pm 0.14^{\mathrm{ab}}$ \\
\hline$\Sigma$ MUFA & $16.78 \pm 0.85^{\mathrm{a}}$ & $23.18 \pm 0.79^{b}$ & $21.19 \pm 0.87^{b}$ \\
\hline$\Sigma$ PUFA & $44.95 \pm 1.04^{\mathrm{a}}$ & $33.67 \pm 0.96^{\mathrm{b}}$ & $38.28 \pm 1.19^{c}$ \\
\hline$\Sigma \omega 3$ PUFA & $10.09 \pm 0.64^{\mathrm{a}}$ & $7.87 \pm 0.56^{\mathrm{b}}$ & $9.39 \pm 0.71^{\mathrm{ab}}$ \\
\hline$\Sigma \omega 6$ PUFA & $34.86 \pm 1.10^{\mathrm{a}}$ & $25.80 \pm 0.88^{b}$ & $28.89 \pm 1.08^{c}$ \\
\hline$\omega 3 / \omega 6$ PUFA & $0.29 \pm 0.06^{\mathrm{a}}$ & $0.31 \pm 0.04^{\mathrm{b}}$ & $0.33 \pm 0.05^{\mathrm{a}}$ \\
\hline
\end{tabular}

Note: different letters indicate values which reliably differed one from another within one line of table according to the results of comparison using Tukey test with Bonferroni correction.

As part of the total serum lipids of sick rats, when the liposomal dietary supplement "FLP-MD" was orally administered to the body with reparative action (experimental group 2), a significant increase in the level of the SFA series was found: caprylic ( $8: 0)$ by 1.7 times, capric (10:0) 1.3 times, lauric (12:0) 1.1 times, margarine (17:0) 2.3 times, of

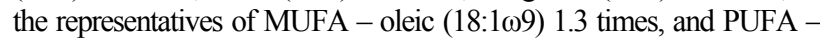

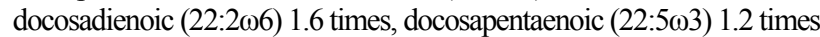
and docosahexaenoic (22:603) 1.1 times, and the total MUFA content was 1.3 times compared with control (Table 1). In this case, the relative amount of PUFA representatives decreases in blood serum: linolenic (18:3 $\omega 3)$ by 2.6 times, cis- $8,11,14$-eicosatriene $(20: 3 \omega 6)$ by 1.5 times,

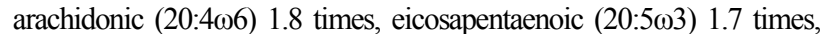
was manifested by a decrease in the relative total PUFA by 1.2 times against a background of a decrease in the relative total $\omega 6$ PUFA by 1.2 times compared to the control.

Changes in the fatty acid composition of serum total lipids of rats were also revealed between the experimental groups 1 and 2 . Thus, a significant increase in the level of the individual SFA was found in the experimental group 2 in comparison with the experimental group 1: caprylic (8:0) by 1.3 times, capric (10:0) by 1.1 times, while the relative amount of PUFA representatives also increased: linoleic $(18: 3 \omega 6)$ by 1.2 times, linolenic $(18: 3 \omega 3)$ by 1.4 times, docosadienoic $(22: 2 \omega 6)$ by 1.8 times, docosapentaenoic $(22: 5 \omega 3)$ by 1.2 times, docosahexaenoic (22:6 $\omega 3)$ by 1.3 times. These changes led to the increase of the total content of UFA by 1.1 times due to the increase in the total PUFA by 1.1 times, notably total $\omega 6$ PUFA by 1.1 times. At the same time, the

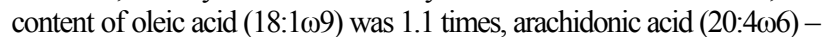
1.4 times, eicosapentaenoic acid (20:5 133$)-1.1$ times lower in the serum lipid fraction of rats of the research group 2 in comparison with the rats of the experimental group 1 . Peculiarities of the serum lipid profile of the rats of the experimental group 2 were quantitative changes in two parameters such as linoleic acid (18:3 $\omega 6)$ and total UFA content: the values of these parameters increased in comparison with the experimenttal group 1 , while these values did not significantly differ from the values of these parameters in the control group. It means the recovery and return of these parameters to the control values. The patterns found indicate intensive reparation processes in the rats of the research group 2.

Short, medium, and long chain fatty acids have also been detected in rat liver. Among SFA, palmitic and stearic dominate. Unsaturated liver fatty acids were heterogeneous: MUFAs were represented by oleic acid; linoleic, arachidonic, and docosahexaenoic acids predominated among PUFAs (Table 2).

Table 2

The fatty acid composition of the total liver lipids of experimental rats ( $\%$ of the total fatty acid content, $\mathrm{x} \pm \mathrm{SD}, \mathrm{n}=20$ )

\begin{tabular}{|c|c|c|c|}
\hline Fatty acid & $\begin{array}{l}\text { Clinically } \\
\text { healthy } \\
\text { animals } \\
\text { (control) }\end{array}$ & $\begin{array}{c}\text { Rats with } \\
\text { tetracycline- } \\
\text { induced hepa- } \\
\text { tosis, self- } \\
\text { rehabilitation }\end{array}$ & $\begin{array}{l}\text { Rats with tetracyc- } \\
\text { line-induced hepato- } \\
\text { sis supplemented } \\
\text { with dietary supple- } \\
\text { ments "FLP-MD" }\end{array}$ \\
\hline Myristine, 14:0 & $0.20 \pm 0.02^{\mathrm{a}}$ & $0.28 \pm 0.02^{\mathrm{b}}$ & $0.21 \pm 0.03^{\mathrm{ab}}$ \\
\hline Pentadecane, $15: 0$ & $0.08 \pm 0.02^{\mathrm{a}}$ & $0.08 \pm 0.01^{\mathrm{a}}$ & $0.08 \pm 0.01^{\mathrm{a}}$ \\
\hline Palmitic, 16:0 & $22.53 \pm 0.57^{\mathrm{a}}$ & $19.75 \pm 0.26^{\mathrm{a}}$ & $20.83 \pm 0.04^{\mathrm{a}}$ \\
\hline Palmitoleic, $16: 1 \omega 9$ & $0.32 \pm 0.03^{\mathrm{a}}$ & $0.41 \pm 0.01^{\mathrm{b}}$ & $0.36 \pm 0.01^{\mathrm{a}}$ \\
\hline Margarine, 17:0 & $0.46 \pm 0.02^{\mathrm{a}}$ & $0.56 \pm 0.01^{\mathrm{b}}$ & $0.51 \pm 0.03^{\mathrm{ab}}$ \\
\hline Stearin, $18: 0$ & $21.26 \pm 0.21^{\mathrm{a}}$ & $18.74 \pm 0.28^{\mathrm{a}}$ & $19.23 \pm 0.18^{\mathrm{a}}$ \\
\hline Olein, $18: 1 \omega 9$ & $6.39 \pm 0.16^{\mathrm{a}}$ & $9.80 \pm 0.11^{\mathrm{b}}$ & $7.55 \pm 0.14^{\mathrm{c}}$ \\
\hline 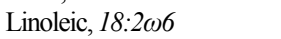 & $20.75 \pm 0.26^{\mathrm{a}}$ & $20.08 \pm 0.12^{\mathrm{ab}}$ & $22.20 \pm 0.19^{\mathrm{a}}$ \\
\hline Peanut, 20:0 & $0.11 \pm 0.01^{\mathrm{a}}$ & $0.13 \pm 0.01^{\mathrm{a}}$ & $0.13 \pm 0.01^{\mathrm{a}}$ \\
\hline Linolenic, $18: 3 \omega 3$ & $0.13 \pm 0.01^{\mathrm{a}}$ & $0.08 \pm 0.01^{\mathrm{b}}$ & $0.10 \pm 0.02^{\mathrm{ab}}$ \\
\hline Gondoic, 20:1 $1 \omega 9$ & $0.21 \pm 0.01^{\mathrm{a}}$ & $0.16 \pm 0.01^{\mathrm{b}}$ & $0.19 \pm 0.02^{\mathrm{ab}}$ \\
\hline $\begin{array}{l}\text { cis-8,11,14-Eicosatriene, } \\
20: 3 \omega 6\end{array}$ & $1.90 \pm 0.08^{\mathrm{a}}$ & $0.03^{\mathrm{b}}$ & 2.1 \\
\hline 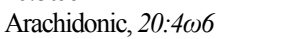 & $12.94 \pm 0.36^{\mathrm{a}}$ & $15.88 \pm 0.24^{b}$ & $11.49 \pm 0.28^{\mathrm{a}}$ \\
\hline Docosadienoic, $22: 2 \omega 6$ & $0.34 \pm 0.02^{\mathrm{a}}$ & $0.30 \pm 0.01^{\mathrm{ab}}$ & $0.37 \pm 0.01^{\mathrm{a}}$ \\
\hline Eicosapentaenoic, $20: 5 \omega 3$ & $2.47 \pm 0.01^{\mathrm{a}}$ & $2.15 \pm 0.03^{\mathrm{b}}$ & $2.84 \pm 0.06^{\mathrm{c}}$ \\
\hline Docosapentaenoic, $22: 5 \omega 3$ & $2.20 \pm 0.04^{\mathrm{a}}$ & $2.06 \pm 0.04^{\mathrm{b}}$ & $2.81 \pm 0.03^{\mathrm{c}}$ \\
\hline Docosahexaenoic, $22: 6 \omega 3$ & $7.71 \pm 0.12^{\mathrm{a}}$ & $6.72 \pm 0.09^{b}$ & $8.91 \pm 0.10^{\mathrm{c}}$ \\
\hline$\Sigma$ SFA & $44.64 \pm 1.43^{\mathrm{a}}$ & $39.52 \pm 1.24^{b}$ & $40.99 \pm 2.19^{\mathrm{ab}}$ \\
\hline$\Sigma$ UFA & $55.36 \pm 1.24^{\mathrm{a}}$ & $60.48 \pm 1.62^{\mathrm{b}}$ & $59.01 \pm 2.06^{\mathrm{ab}}$ \\
\hline SFA UFA & $0.81 \pm 0.06^{\mathrm{a}}$ & $0.65 \pm 0.02^{\mathrm{b}}$ & $0.70 \pm 0.09^{\mathrm{ab}}$ \\
\hline$\Sigma$ MUFA & $6.92 \pm 0.32^{\mathrm{a}}$ & $10.37 \pm 0.71^{\mathrm{b}}$ & $8.10 \pm 0.56^{\mathrm{ab}}$ \\
\hline$\Sigma$ PUFA & $48.44 \pm 2.01^{\mathrm{a}}$ & $50.11 \pm 2.31^{\mathrm{a}}$ & $50.91 \pm 1.98^{\mathrm{a}}$ \\
\hline$\Sigma \omega 3$ PUFA & $12.51 \pm 0.94^{\mathrm{a}}$ & $11.01 \pm 0.65^{\mathrm{ab}}$ & $14.66 \pm 0.87^{\mathrm{a}}$ \\
\hline$\Sigma \omega 6$ PUFA & $35.93 \pm 1.04^{\mathrm{a}}$ & $39.10 \pm 0.44^{b}$ & $36.25 \pm 1.15^{\mathrm{a}}$ \\
\hline$\omega 3 / \omega 6$ PUFA & $0.35 \pm 0.02^{\mathrm{a}}$ & $0.28 \pm 0.01^{\mathrm{b}}$ & $0.40 \pm 0.01^{\mathrm{c}}$ \\
\hline
\end{tabular}

Note: see Table 1.

A feature of the fatty acid spectrum of total lipid tissue of liver tissue of rats with tetracycline-induced hepatosis (experimental group 1) was an increase in the content of two representatives from SFA: myristic acid (14:0) 1.4 times, margaric acid (17:0) 1.2 times; with MUFA: palmitoleic acid $(16: 1 \omega 9) 1.3$ times, oleic acid $(18: 1 \omega 9) 1.5$ times; with PUFA: cis8,11,14-eicosatrienoic acid (20:3 $\omega 6) 1.5$ times and arachidonic acid (20:406) 1.2 times compared with the control. In accordance with established laws, the relative total UFA content increased by 1.1 times and MUFA by 1.5 times. At the same time, in these animals there was a decrease in the content of gondoic acid with MUFA $(20: 1 \omega 9)$ of 1.2 times in the lipid fraction of the liver tissue and a 1.6-fold number of PUFA: linole- 


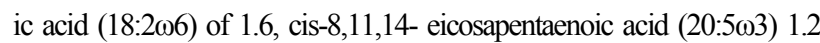
times, docosapentaenoic acid (22:5 1.2 3) 1.2 times, docosahexaenoic acid (22:6 13 3) 1.2 times compared with the control. This led to a decrease in the relative total amount of SFA by 1.1 times and the ratio of the relative total content of SFA/UFA and $\omega 3 / \omega 6$ PUFA, respectively, by 1.3 times.

Along with this, differences were found in both quantitative and qualitative characteristics of the studied parameters in the liver of rats of experimental group 2, to which the liposomal dietary supplement "FLP-MD" of reparative action was introduced into the body for corrective purposes. So, in the structure of the lipid tissue of the liver tissue of these animals, an increase in the content of UFA was noted. In particular, the representative of MUFA - oleic acid (18:1 $\omega 9) 1.2$ times, from the PUFA class: cis8,11,14-eicosatrienoic acid (20:3 $\omega 6) 1.2$ times, eicosapentaenoic acid (20:5 133$) 1.2$ times, docosapentaenoic acid $(22: 5 \omega 3)$ by 1.3 times and docosahexaenoic acid (22:6 103$)$ by 1.2 times compared with the control. In addition, in rats of this group, there was a 1.1 times increase in the ratio $\omega 3 / \omega 6$ PUFA, which indicates the anti-inflammatory effect of the components of the dietary supplement. The content of representatives of the SFA class in the lipid fraction of the liver tissue of these animals was restored and corresponded to the boundaries of the control values. The changes in the fatty acid composition of total blood serum lipids and liver tissue in animals of experimental group 2 were determined. They differ from those in sick rats during self-rehabilitation (research group 1) and they mainly relate to four representatives of the PUFA class - docosadienoic, eicosapentaenoic, docosapentaenoic and docosahexaenoic acids, can act markers of the development of the pathological process (hepatodystrophy) and criteria for the hepatoprotective effectiveness of new drugs.

In addition, recovery and return to control levels was observed for individual representatives (and their total content) of fatty acids of liver total lipids of the rats of the experimental group 2. In this case, values of these parameters differ significantly from these in the rats of the experimental group 1 . This particularly applies to the acids of UFA class: palmitoleic

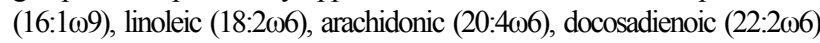
acids, total $\omega 3$ PUFA and total $\omega 6$ PUFA. Thus, the level of linoleic

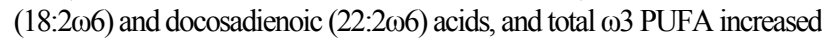
significantly by 1.1, 1.2 and 1.3 times, respectively in comparison with the experimental group 1 . At the same time, the level of palmitoleic $(16: 1 \omega 9)$, arachidonic (20:4 $\omega 6)$ and total $\omega 6$ PUFA decreased significantly by 1.1 , 1.4 and 1.1 times respectively. In addition, the level of several individual acids in the liver total lipids of the rats of the experimenttal group 2 differed significantly from both levels of these acids in the experimental group 1 and control group (as described above). These changes apply to

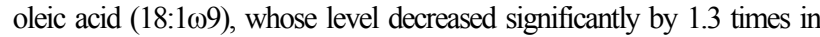
the liver lipids of the rats of the experimental group 2 in comparison with the experimental group 1 . This also applies to the significantly increased by 1.3 times levels of cis-8,11,14-eicosatrienoic $(20: 3 \omega 6)$, eicosapentae-

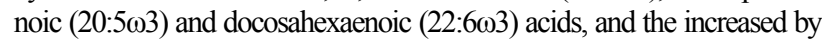
1.4 times value of the $\omega 3 / \omega 6$ PUFA ratio in the liver lipids of these animals in comparison with the rats of the experimental group 1.

Thus, as a result of a chromatographic study of the fatty acid composition of total blood serum lipids and rat liver tissue during tetracyclineinduced hepatosis, a number of characteristic changes have been established that are inherent in sick animals and distinguish them from rats that underwent reparative therapy in the form of liposomal dietary supplement "FLP-MD". First of all, they concern the content of four representatives of PUFA.

\section{Discussion}

With tetracycline-induced hepatosis in rats, a deep qualitative and quantitative rearrangement of the acyl composition of the total lipids of the blood serum and liver of rats is observed, which is also noted in other pathological conditions described in (Gula \& Margitich 2009; Grattagliano et al., 2013; Nedoshytko, 2013; Colombo et al., 2018).

The most pronounced changes in the fatty acid composition of the blood serum lipids of rats suffering from toxic dystrophy due to the use of high doses of tetracycline hydrochloride were an increase in the relative content of caprylic acid (8:0) by 1.3 times (SFA), margarine (17:0) by 2.3 times (SFA), oleic (18:1 19 ) 1.4 times (MUFA) and a decrease in the

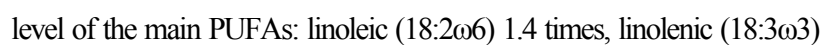

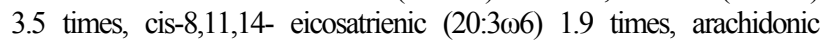

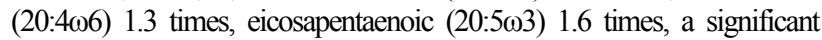
increase in the blood serum of sick rats with total quantity and MUFA by 1.4 times and a decrease in the total values of PUFA, $\omega 3$ PUFA and $\omega 6$ PUFA, respectively 1.3 times, 1.3 and 1.4 times compared with the control. In turn, a decrease in the number of PUFAs, primarily docosahexa-

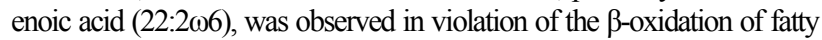
acids in mitochondria, which, as is known, is characteristic of the development of other pathological conditions: cardiovascular diseases, malignant neoplasms, acute ischemic damage to the liver and myocardium, when animals are exposed to ionizing radiation, etc. (Gula \& Margitich, 2009). At the same time, characteristic changes in the liver tissue of sick animals were an increase in the lipid content of myristic acid (14:0) (SFA) by 1.4 times, palmitoleic (16:1) (MUFA) 1.3 times, and oleic (18:1 $\omega 9$ ) (MUFA) 1.5 times, cis-8,11,14-eicosatrienic (20:3 $\omega 6$ ) (PUFA) 1.5 times, an increase in the relative content of $\Sigma$ MUFA by 1.5 times, a decrease in linoleic acid (18:2 $\omega 6$ ) (PUFA) by 1.6 times and the magnitude of the ratios of the total content of SFA/UFA by 1.3 times and $\omega 3 / \omega 6$ PUFA by 1.3 times compared with the control (Fig. 1). The described regularities with respect to quantitative changes in both individual fatty acids and their ratios in the structure of total serum lipids and liver tissue with experimental reproduction in rats with tetracycline lesion of the latter indicate both activation of the lipid peroxidation process and metabolic disorders of essential fatty acids. This significantly affects the structural organization of the lipid component of cell membranes, which causes a decrease in their fluidity, impaired functioning of receptors and membrane-bound enzymes. As a result, metabolic disorders in hepatocytes occur and the pathological process progresses (Nedoshytko, 2013). The above convinces us of the necessity of using reparative therapy for sick animals. This group of therapeutic agents includes the Acad, developed at the Department of Animal Biochemistry and Physiology M.F. Gulogo liposomal dietary supplement "FLP-MD", which is made on the basis of milk phospholipids, a complex of unsaturated fatty acids (oleic, linoleic, linolenic) and antioxidant vitamins $\mathrm{A}$ and $\mathrm{E}$.

As a result of the introduction of the reparative action of the liposomal dietary supplement "FLP-MD" into the organism of sick rats (experimenttal group 2), the development of the body's adaptive response is noted (Fig. 2), which, first of all, manifests itself in a significant increase in the

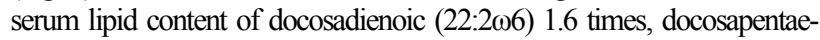
noic $(22: 5 \omega 3) 1.2$ times and docosahexaenoic (22:6 133$) 1.1$ times acids, accompanied by a decrease in the relative total PUFA content by 1.2 times due to pro-inflammatory factors - $\omega 6$ fatty acids (in $1.2 \mathrm{p}$ for). And in the liver of these animals a 1.2-fold increase in the content of eicosatrienic

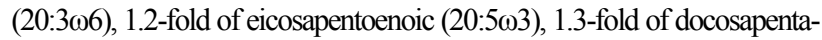

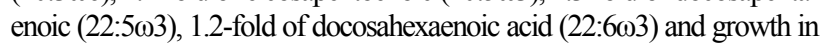
the ratio of the relative content of $\omega 3 / \omega 6$ PUFA is 1.1 times. Moreover, in rats (experimental group 1) in conditions of self-rehabilitation, changes in the fatty acid composition of blood serum and liver lipids were revealed, which differed in the opposite direction. In particular, there was a decrease in the level of docosadienoic and docosahexanoic acids (PUFA), as well as $\Sigma$ PUFA by 1.3 times against the background of a decrease in the relative content of the sum of $\omega 3$ fatty acids by 1.3 times, which confirms the progression of inflammatory processes in these animals.

At the same time, studies of the fatty acid composition of liver tissue in rats with tetracycline-induced hepatosis showed that key changes are primarily experienced by PUFA class acids, namely: a 1.2-fold decrease in the relative content of eicosapentaenoic (20:5 $\omega 3)$, docosapentaenoic

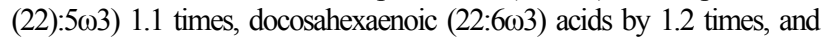
the total SFA by 1.1 times and the ratio of the relative contents of SFA/UFA and $\omega 3 / \omega 6$ PUFA, respectively by 1.3 times. As is known (Madian, 2015; Kagebeck et al., 2018), this can lead to disruption of membrane-bound functions and metabolic processes at the level of affected cells, which enhances the course of the pathological process. The use of milk phospholipids and an essential fatty acid complex in the form of a liposomal form of dietary supplement "FLP-MD" of reparative action for sick animals provides almost complete restoration of the level of most representatives of SFA and UFA. A series of these parameters returns to the control values, while at the same time they differ significantly from th 
ose in sick animals in conditions of self-rehabilitation. This particular of the fatty acid profile applies to the level of linoleic acid (18:2 $\omega 6)$ and total

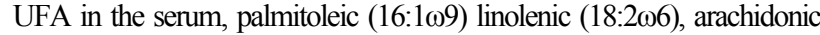

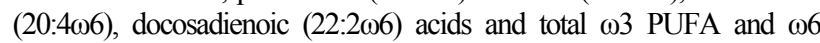
PUFA in the liver tissue of rats. However, among all of the studied para-

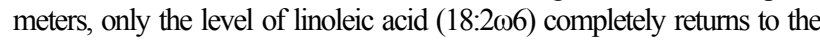
control values in the serum, as well as in the liver of this group of animals, while it significantly increases in comparison with the group of animals in conditions of self-rehabilitation. The patterns found allow us to conclude that anti-inflammatory effect in terms of the fatty acid profile is more pronounced in the liver than in the serum of the studied animals. During our study, significant changes in 6 of 25 studied parameters of the fatty acid spectrum were revealed in the serum, as well as in the liver of the rats treated with "FLP-MD" dietary supplement. These changes allow us to consider these parameters as the markers of the rehabilitation process. And these parameters are oleic (18:1 19$)$, linoleic $(18: 2 \omega 6)$, arachidonic

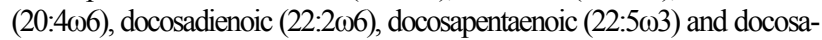
hexaenoic $(22: 6 \omega 3)$ acids.

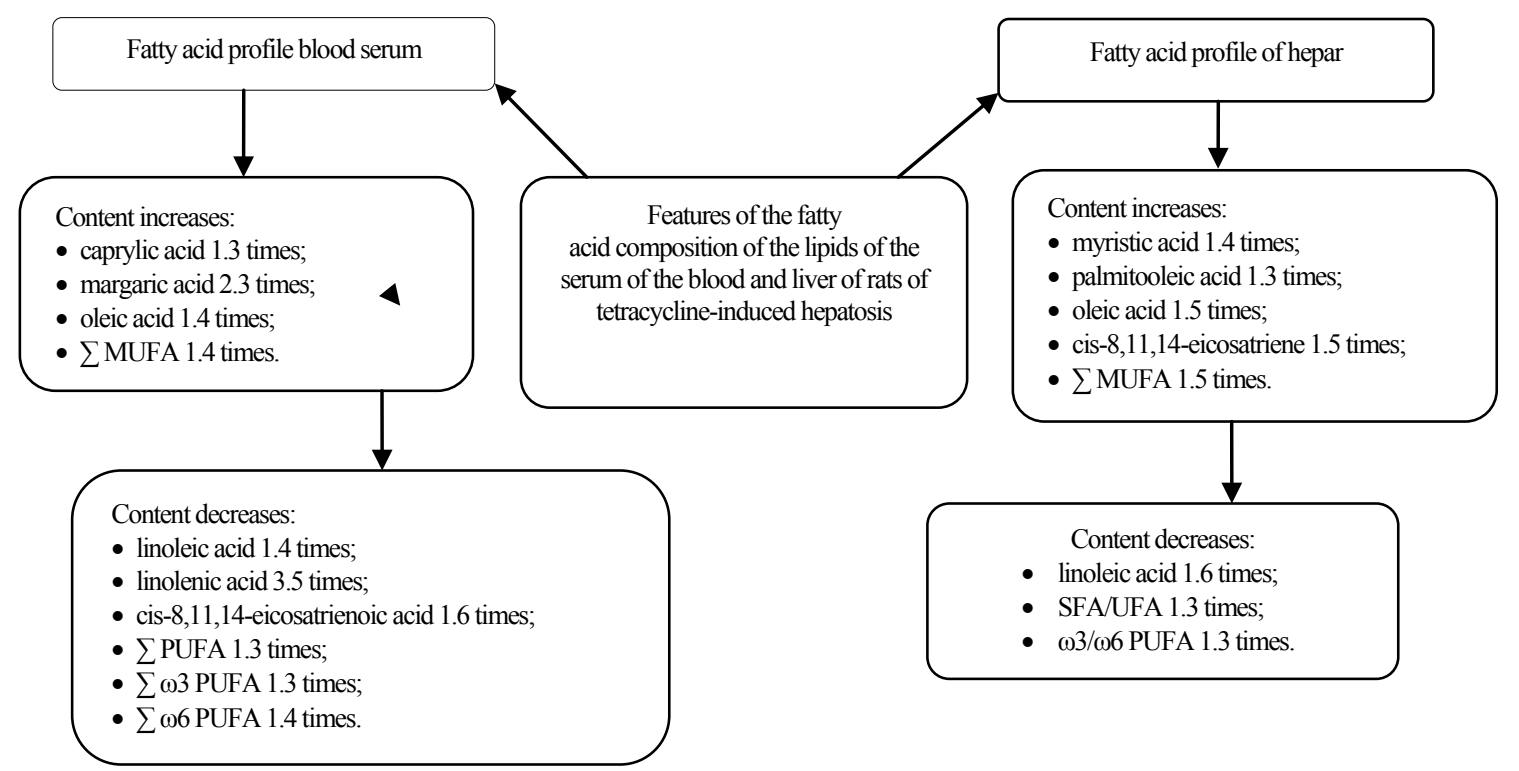

Fig. 1. Characteristic changes in the fatty acid composition of serum and liver lipids of rats with tetracycline-induced hepatosis

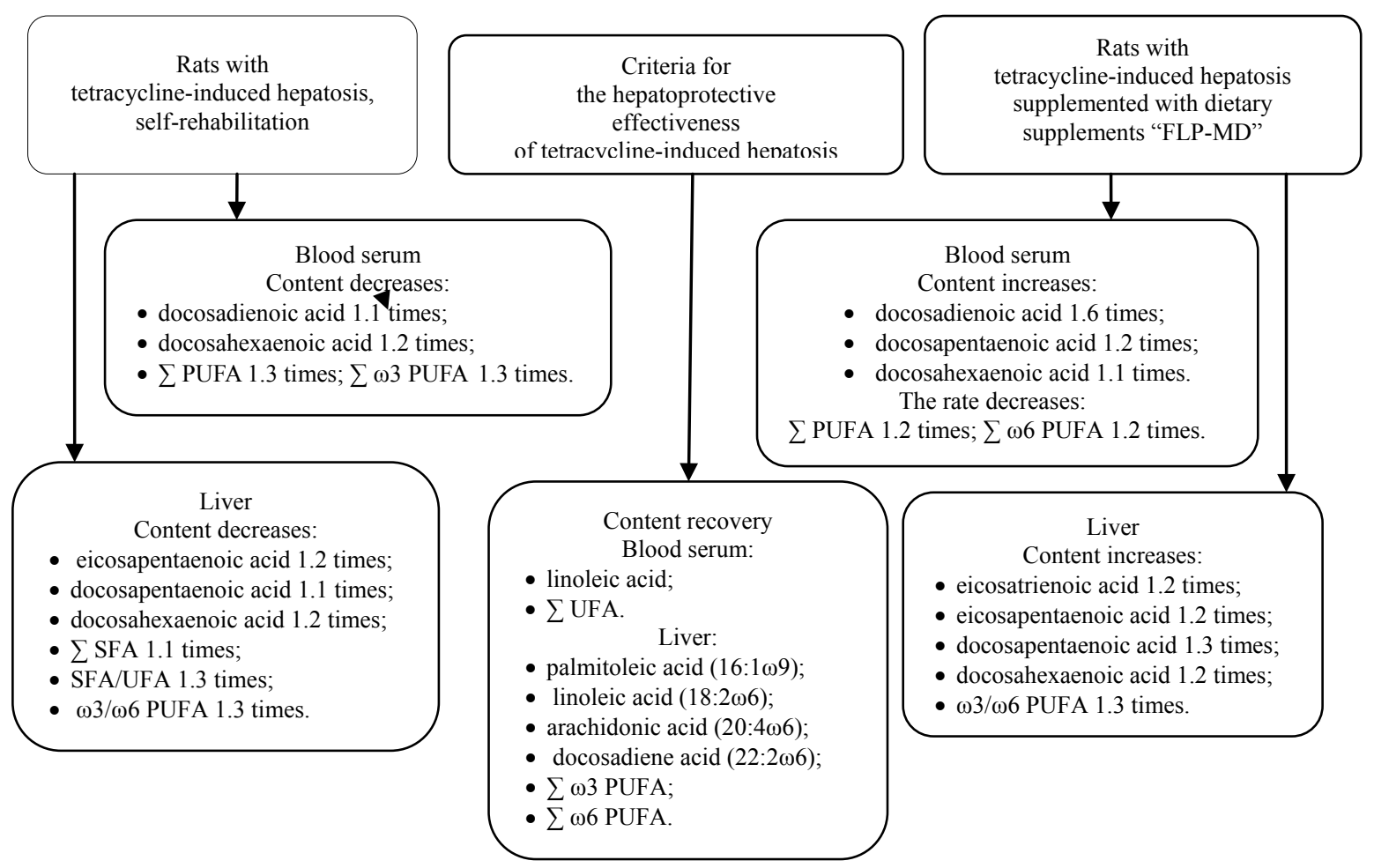

Fig. 2. Indicators of the hepatoprotective efficacy of milk phospholipids in the liposomal form of dietary supplement "FLP-MD" in tetracycline-induced rat hepatosis

Thus, the hepatoprotective effect of dietary supplements "FLP-MD" when applied to animals sick with tetracycline-induced hepatosis is prima- rily realized due to compensation for the imbalance of fatty acids in the blood serum and liver tissue, as a result of restoration of the structural or- 
ganization and functional state of the affected hepatocytes and additional intake of deficient biologically active substances in the body as a part of a dietary supplement.

\section{Conclusion}

Regularities were established experimentally regarding the fatty acid composition of the blood serum and liver of rats of toxic liver damage with the antibiotic tetracycline, which allowed us to determine indicators by which toxic liver damage can be diagnosed and preclinical trials of the hepatoprotective efficacy of new drugs can be performed. First of all, this applies to the four fatty acids of the PUFA class and the correlation of indicators corresponding to these changes. Such fatty acids in the blood

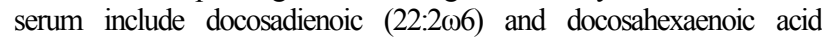
(22:6 $\omega 3$ ), as well as the total content of PUFA and $\omega 3$ PUFA, and in the liver tissue - eicosapentaenoic (20:5 $\omega 3)$, docosapentaenoic (22:5 13$)$, docosahexaenoic (22:6 $\omega 3)$ acid and the ratio of the total content of SFA/UFA and $\omega 3 / \omega 6$ PUFA. The parameters of these indicators experienced an increase in the range of 1.1-1.3 times with the use of the liposomal form of dietary supplement "FLP-MD" of reparative action compared with the control. Moreover, in self-rehabilitation rats, the indices described are, on the contrary, characterized by a significant decrease in their parameters in a similar range. At the same time, complete recovery and return to the control values was observed for two parameters in the

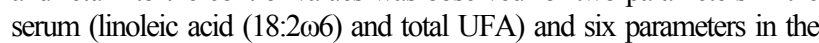

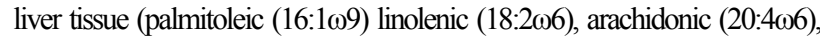
docosadienoic (22:2 $\omega 6$ ) acids and total $\omega 3$ PUFA and $\omega 6$ PUFA). In general, certain changes in the fatty acid composition of the total lipids of blood serum and liver tissue indicate the prospect of further studies of lipid metabolism disorders in animals with toxic liver dystrophy caused by drug damage.

\section{References}

Bothra, A., Arumugam, P., Panchal, V., Menon, D., Srivastava, S., Shankaran, D., Nandy, A., Jaisinghani, N., Singh, A., Gokhale, R. S., Gandotra, S., \& Rao, V. (2018). Phospholipid homeostasis, membrane tenacity and survival of $\mathrm{Mtb}$ in lipid rich conditions is determined by MmpL11 function. Scientific Reports, 8317, 1-14.

Calitz, C., Hamman, J. H., Fey, S. J., Wrzesinski, K., \& Gouws, C. (2018). Recent advances in three-dimensional cell culturing to assess liver function and dysfunction: From a drug biotransformation and toxicity perspective. Toxicology Mechanisms and Methods, 28(5), 369-385.

Christive, W. W. (1982). Lipid analysis: Isolation, separation, identification and structural analysis of lipids. 2nd edn. Pergamon Press, Oxford.

Colombo, S., Melo, T., Martinez-Lopez, M., Carrasco, M. J., Domingues, P., Pérez-Sala, D., \& Domingues, R. (2018). P-150 - Phospholipidome of endothelial cells shows a different adaptation response upon oxidative, glycative or carbonyl stress. Free Radical Biology and Medicine, 120(1), S90.

Fabbrini, E., \& Magkos, F. (2015). Hepatic steatosis as a marker of metabolic dysfunction. Nutrients, 7(6), 4995-5019.

Fan, C.-Y., Pan, J., Usuda, N., Yeldandi, A. V., Rao, M. S., \& Reddy, J. K. (1998). Steatohepatitis, spontaneous peroxisome proliferation and liver tumors in mice lacking peroxisomal fatty acyl-CoA oxidase. Journal of Biological Chemistry, 273(25), 15639-15645.
Folch, J., Lees, M., \& Sloane-Stanley, G. H. (1957). A simple method for the isolation and purification of total lipides from animal tissues. Journal of Biological Chemistry, 226(1), 497-509.

Grattagliano, I., Diogo, C. V., Mastrodonato, M., de Bari, O., Persichella, M. Wang, D. Q., Liquori, A., Ferri, D., Carratù, M. R., Oliveira, P. J., \& Portincasa, P. (2013). A silybin-phospholipids complex counteracts rat fatty liver degeneration and mitochondrial oxidative changes. World Journal Gastroenterology, 19(20), 3007-3017.

Gryshchenko, V., Danchenko, O., \& Musiychuk, V. (2019). Modification of modeling methods toxic hepatodistrophy in rats. In: Nadykto, V. (Ed.). Modern development paths of agricultural production. Springer, Cham.

Gryshchenko, V. A., Sysolyatin, S. V., \& Gulevata, J. V. (2018). Phospholipid composition of blood plasma and internal organs of rats with diclofenacinduced hepatitis. Ukrainian Journal of Ecology, 8(3), 235-240.

Gula, N. M., \& Margitich, V. M. (2009). Zhymi kysloty ta yikh pokhidni pry patolohichnykh stanakh [Fatty acids and their derivatives in pathologic states]. Naukova Dumka, Kyiv (in Ukrainian).

Jump, D. B., \& Clarke, S. D. (1999). Regulation of gene expression by dietary fat. Annual Review of Nutrition, 19, 63-90.

Kagebeck, P., Nikiforova, V., Brunken, L., Easwaranathan, A., Ruegg, J., Cotgreave, I., \& Munic, K. V. (2018). Lysosomotropic cationic amphiphilic drugs inhibit adipocyte differentiation in 3T3-L1K cells via accumulation in cells and phospholipid membranes, and inhibition of autophagy. European Journal of Pharmacology, 829, 44-53.

Madian, A. G. (2015). Redox proteomic investigation of tetracycline-induced steatosis. Proteomics, 15(1), 8-9.

Melnychuk, D. O., Gryshchenko, V. A., \& Lytvynenko, O. N. (2009). Veterynarna biologichno aktyvna dobavka liposomal'noi' formy ta sposib reparatyvnoi' terapii' $v$ gepatologii' [Veterinary biologically active additive of liposomal form and method of reparative therapy in hepatology]. Patent UA, 86516 (in Ukrainian).

Nedoshytko, K. Y. (2013). Zminy prooksydantno-antyoksydantnoi' systemy pechinky shhuriv za dii' etylovogo spyrtu ta tetracyklinu [Alterations of prooxidantant and oxidant system of rat liver exposed to ethanol and tetracycline action]. Ukrainian Biochemical Journal, 85(5), 154-162 (in Ukrainian).

Peter, J. S., \& Prince, S. E. (2018). Diclofenac-induced renal toxicity in female Wistar albino rats is protected by the pre-treatment of aqueous leaves extract of Madhuca longifolia through suppression of inflammation, oxidative stress and cytokine formation. Biomedicine and Pharmacotherapy, 98(12), 45-51.

Quinn, P. J. (2014). Sphingolipid symmetry governs membrane lipid raft structure. Biochimica et Biophysica Acta, 1838(7), 1922-1930.

Udut, V. V., Vengerovsky, A. I., \& Dygai, A. M. (2013). Effects of phospholipid hepatoprotectors on apoptosis during experimental liver pathology induced by isoniazid and paracetamol. Bulletin of Experimental Biology and Medicine, 154(5), $614-617$.

Vlizlo, V. V., Fedoruk, R. S., \& Ratych, I. B. (2012). Laboratorni metody doslidzhen u biolohiyi, tvarynnytstvi ta veterynarniy medytsyni [Laboratory methods of investigation in biology, stock-breeding and veterinary]. Spolom, Lviv (in Ukrainian).

Wei, F., Wang, X., Ma, H.-F., Lv, X., Dong, X.-Y., \& Chen, H. (2018). Rapid profiling and quantification of phospholipid molecular species in human plasma based on chemical derivatization coupled with electrospray ionization tandem mass spectrometry, Analytica Chimica Acta, 1024, 101-111.

Yang, K. J., Son, J., Jung, S. Y., Yi, G., Yoo, J., Kim, D. K., \& Koo, H. (2018). Optimized phospholipid-based nanoparticles for inner ear drug delivery and therapy. Biomaterials, 171(7), 133-143.

Yu, H. Y., Wang, B. L., Zhao, J., Yao, X. M., Gu, Y., \& Li, Y. (2009). Protective effect of bicyclol on tetracycline-induced fatty liver in mice. Toxicology, 261(3), 112-118. 